\title{
Infection dynamics across the dry period using Dairy Herd Improvement somatic cell count data and its effect on cow performance in the subsequent lactation
}

\author{
Z. Lipkens, ${ }^{1}$ S. Piepers, ${ }^{1}$ J. Verbeke ${ }^{2}$ and S. De Vliegher ${ }^{1 *}$ \\ ${ }^{1}$ M-team and Mastitis and Milk Quality Research Unit, Department of Reproduction, Obstetrics and Herd Health, Faculty of Veterinary Medicine, \\ Ghent University, 9820 Merelbeke, Belgium \\ ${ }^{2}$ Poulpharm, 8870 Izegem, Belgium
}

\section{ABSTRACT}

In this study, we studied infection dynamics across the dry period using test-day somatic cell count (SCC) data from 739 Holstein cows from 33 randomly selected commercial dairy herds in Flanders, all of which applied blanket dry-cow therapy at dry-off. First, we determined infection dynamics, combining the last testday SCC before dry-off and the first test-day SCC after calving. Next, we determined the effect of dry period infection dynamics, adjusting for the level of the second test-day SCC after calving, on the evolution of testday SCC and milk yield (MY) and on clinical mastitis and culling hazard in the subsequent lactation. Using an SCC threshold of 200,000 cells $/ \mathrm{mL}, 12.6 \%$ of the cows considered healthy before dry-off acquired a new intramammary infection (IMI) across the dry period, whereas $66.9 \%$ of the cows considered infected before dry-off cured from IMI. Infection dynamics across the dry period significantly affect a cow's SCC, clinical mastitis risk, and culling hazard in the subsequent lactation. Cows with a new IMI, a cured IMI, or a chronic IMI across the dry period had higher test-day SCC than healthy cows, and their test-day SCC evolved differently over time. This was not the case for test-day milk yield, for which no association with infection dynamics was detected. Furthermore, cows with a second test-day SCC $<200,000$ cells/mL had a lower test-day SCC in the remainder of the lactation than cows with a second test-day $\mathrm{SCC} \geq 200,000$ cells $/ \mathrm{mL}$, but this association was modified by infection dynamics across the dry period. The lowest test-day SCC in the remainder of the lactation was observed for cows that remained healthy across the dry period combined with a low $(<200,000$ cells $/ \mathrm{mL}$ ) second test-day SCC. Cows that cured from

Received May 30, 2018.

Accepted September 13, 2018.

*Corresponding author: Sarne.Devliegher@UGent.be an IMI present at dry-off and cows with a chronic IMI across the dry period were more likely to develop clinical mastitis (hazard ratio $=2.22$ and $2.89 ; 95 \%$ confidence interval $=1.45-3.43$ and $1.60-5.20$, respectively), and chronic IMI cows were more likely to be culled (hazard ratio $=3.68 ; 95 \%$ confidence interval $=1.64-8.20)$ in the subsequent lactation compared with healthy cows. This was not true for cows that became infected across the dry period. This study underlines the importance of good udder health management during lactation to prevent IMI at dry-off rather than curing infected cows during the dry period to ensure optimal udder health in the subsequent lactation.

Key words: dry period, infection dynamics, impact on cow's performance

\section{INTRODUCTION}

Milk and dairy products are consumed around the world by billions of people, and global milk demand is still increasing (Bai et al., 2018). To further increase production in an ecologically and economically responsible manner, investing in optimal udder health and robust cattle is necessary. For dairy cows, the dry period is an important period for udder health because dry cows can cure from IMI present at dry-off (Bradley and Green, 2000; Dingwell et al., 2004) but udder health can also be threatened as many cows acquire new IMI in the dry period (Bradley and Green, 2000, 2001; Whist and Østeras, 2007).

Milk somatic cell counting is a valuable instrument for monitoring udder health in lactating cows and is often used as a proxy for IMI (Dufour et al., 2011; Dufour and Dohoo, 2012). In contrast to bacteriological culture results, SCC data can be easily obtained from DHI records, providing SCC values at the individual cow level at regular intervals. The SCC cut-off generally suggested in literature to predict IMI is 200,000 cells/ mL (Dohoo et al., 1981; Pantoja et al., 2009a). Using this threshold and based on the last SCC record before 
dry-off and the first SCC record after calving, infection dynamics across the dry period have been studied in Wisconsin (Cook et al., 2002; Pantoja et al., 2009a), Quebec (Canada; Fauteux et al., 2014) and the UK (Madouasse et al., 2010), confirming the importance of monitoring dry period infection dynamics because it allows producers to adapt dry-cow management practices. Still, only a few studies have described the impact of infection dynamics on performance in the subsequent lactation. Green et al. (2002) and Pantoja et al. (2009b) reported that quarters that remained chronically infected across the dry period had a higher likelihood of developing clinical mastitis (CM) in the first 120 DIM compared with those that remained healthy. However, the odds of developing CM in newly infected and cured quarters only slightly differed from the odds in quarters remaining healthy (Pantoja et al., 2009b). It remains to be studied whether the same is true for cows as for quarters. Whether dry-period infection dynamics affect culling hazard and the evolution of test-day SCC and milk yield (MY) in the subsequent lactation also remains to be determined. It should not be ignored that both the innate and acquired immunity are compromised during the transition period (Wankhade et al., 2017), which can lead to an overestimation of the capacity of leukocytes present in the milk in early lactation. For that reason, when studying the effect of dry-period infection dynamics, taking into account the second test-day SCC after calving, when the immune system has regained capacity, might help predict the test-day performance in the subsequent lactation more accurately.

The objectives of this study were (1) to describe infection dynamics across the dry period from a large number of cows on randomly selected Flemish commercial dairy farms using DHI test-day SCC data before dry-off and after calving; and (2) to quantify the effect of infection dynamics across the dry period on the evolution of test-day SCC and milk yield and on CM and culling hazards in the subsequent lactation, taking into account the second test-day SCC after calving.

\section{MATERIALS AND METHODS}

\section{Herds, Cow and Udder Health, Clinical Mastitis, and Culling Data}

The database for the current research originated from another study conducted in Flanders (Verbeke et al., 2014) that enrolled 50 out of 67 randomly selected herds from the Milk Control Center (MCC Flanders, Lier, Belgium) database, by use of the Excel RAND function (Excel 2010; Microsoft Corp., Redmond, WA). During the study period between September 2012 and
October 2013, the producers monitored CM events in the herd. Of the 50 herds, 33 participated in the local DHI program of the cooperative cattle improvement organization (CRV, Sint-Denijs-Westrem, Belgium), providing cow-level SCC and MY data as well as culling information for 3,128 cows. These herds were geographically scattered over the 5 provinces of Flanders: East Flanders $(\mathrm{n}=12)$, West Flanders $(\mathrm{n}=8)$, Antwerp $(\mathrm{n}=7)$, Limburg $(\mathrm{n}=4)$, and Flemish Brabant $(\mathrm{n}=$ 2). All producers applied blanket dry-cow therapy with either a narrow- ( $\mathrm{n}=1$; cefalexin) or broad-spectrum antibiotic tube ( $\mathrm{n}=32$; cefquinome, cloxacillin, combination of cloxacillin and ampicillin, rifaximin). Most producers additionally applied internal teat sealers (n $=28$ ), whereas some herds never or only sometimes applied an internal teat sealer $(\mathrm{n}=2$ and $\mathrm{n}=3$, respectively). All herds milked Holstein-Friesian cows, mostly in a conventional milking parlor $(\mathrm{n}=30)$. In the other herds, cows were milked using an automatic milking system $(\mathrm{n}=2)$ or in a tiestall $(\mathrm{n}=1)$. The herd size averaged 69 lactating cows (range of 27 to 240 lactating cows).

To be included in the study, any cow was required to have a DHI record at a maximum of $42 \mathrm{~d}$ before dry-off and at least 2 DHI records after calving. Additionally, only cows with a first DHI record between 12 (Dohoo, 1993) and 42 DIM were kept in the data set, resulting in 33 herds housing 739 cows with 3,311 DHI records available for analyses, referred to as data set "test-day" (Table 1). The parity after calving of each cow and DIM at test-day were available via DHI records. Each cow contributed 1 lactation to the data set and needed at least $1 \mathrm{DHI}$ record before dry-off and at least $2 \mathrm{DHI}$ records after calving to be included. As the exact dates of dry-off were not available for the individual cows, they were considered dried off halfway between the last DHI record and the next DHI recording taking place in the herd, resulting in a herd-average dry period length of $53 \mathrm{~d}$ (ranging between 43 and $65 \mathrm{~d}$ ). Overall, the interval between DHI recordings ranged between 21 and $58 \mathrm{~d}$. To be able to adjust for the level (high or low) of the second test-day SCC after calving, a subset of the data set "test-day" was created (subset "test-day-sub"). Again, 1 DHI record before dry-off and a minimum of 3 DHI-records after calving in this case were required for a cow to be included (Table 1).

Additionally, starting from data set "test-day," 2 more data sets were created to study potential associations between dry period infection dynamics and the hazard of developing CM (data set "CM") and the culling hazard (data set "culling") in the subsequent lactation (Table 1). In data set "CM," data from 2 herds (29 cows) were not included because they failed to collect samples of each CM case (Verbeke et al., 2014). Cows 
without CM data $(\mathrm{n}=13)$ and cows suffering from a CM case before their first DHI record $(\mathrm{n}=11)$ were excluded from further analyses.

\section{Infection Dynamics Based on DHI Records Across the Dry Period}

Cows with an elevated SCC $(\geq 200,000$ cells $/ \mathrm{mL})$ were considered infected, whereas cows with an SCC $<200,000$ cells/mL were considered uninfected. Infection dynamics across the dry period were defined using test-day SCC at the last DHI record measured within 6 wk before dry-off and the first DHI record after calving, measured between $12 \mathrm{~d}$ (Dohoo, 1993) and 6 wk postcalving. This resulted in an interval from 56 to $156 \mathrm{~d}$.

Using the test-day SCC before dry-off and after calving, cows were defined as (1) healthy: test-day SCC $<200,000$ cells $/ \mathrm{mL}$ before and after the dry period; (2) newly infected: test-day SCC $<200,000$ cells $/ \mathrm{mL}$ before the dry period and $\geq 200,000$ cells/mL after the dry period; (3) cured from an existing IMI: test-day $\geq 200,000$ cells/mL before the dry period and $<200,000$ cells $/ \mathrm{mL}$ after the dry period; and (4) chronically infected: testday SCC $\geq 200,000$ cells/mL before and after the dry period.

The new IMI risk was calculated by dividing the number of cows with a new IMI by the total number of cows being healthy at dry-off. The cured IMI risk was calculated by dividing the number of cows with cured IMI by the total number of infected cows at dry-off.

\section{Performance in the Subsequent Lactation}

Test-Day SCC and MY. Individual SCC $(\times 1,000$ cells per $\mathrm{mL}$ ) and composite MY (kg of milk/d) at testday per cow were available from DHI records. The first test-day SCC was measured between 12 and 42 DIM, and the second test-day SCC was measured between 34 and 93 DIM. The cow performance variables test-day SCC and MY in the data set "test-day" were measured from 30 to 285 DIM, whereas in subset "test-day-sub," DIM ranged from 63 to 285.

$C M$ and Culling. Signs of CM were defined as visible abnormalities of the udder or milk (absence or presence of clots in milk, a hard quarter, or systemic illness), indicating udder inflammation, and were observed by the farmer by examination of the udder and foremilk before milking. In herds with an automated milking system, producers examined foremilk and the udder of cows with changes in sensor data (electrical conductivity, color, and yield), reduced milking frequency, or visual abnormalities (e.g., swelling or redness of the udder) (Verbeke et al., 2014). Culling date of cows that were culled for any reason were retrieved from DHI records. Only CM cases and culling events between 12 and 285 DIM were included in data set "CM" and data set "culling," respectively.

\section{Statistical Analyses}

Test-Day SCC and MY. The association between infection dynamics across the dry period (predictor variable of main interest) and test-day LnSCC (natural logarithmic transformation of SCC to normalize the data) or MY (outcome variables), respectively, was determined using linear mixed regression models (PROC MIXED, SAS 9.4, SAS Institute Inc., Cary, NC) using data set "test-day." Herd was included as a random effect. The model was fit also including DIM and the quadratic term for DIM $\left(\mathrm{DIM}^{2}\right)$ as continuous predictor variables, and infection dynamics across the dry period (i.e., healthy, newly infected, cured from an existing IMI, and chronically infected) and parity (3 levels: 2, 3, and $\geq 4$ ) as categorical predictor variables. A weighting

Table 1. Structure of the data

\begin{tabular}{|c|c|c|c|c|}
\hline Data & Level & $\mathrm{n}$ & $\begin{array}{l}\text { Average number per } \\
\text { unit at next higher level }\end{array}$ & Range \\
\hline \multirow[t]{3}{*}{ Data set "test-day"1 } & Herds & 33 & - & \\
\hline & Cows & 739 & 22 & $4-65$ \\
\hline & DHI records & 3,311 & 4.48 & $1-10$ \\
\hline \multirow[t]{3}{*}{ Subset "test-day-sub"2 } & Herds & 33 & — & \\
\hline & Cows & 640 & 19 & $2-60$ \\
\hline & DHI records & 2,485 & 3.88 & $1-9$ \\
\hline \multirow{2}{*}{ Data set "CM" } & Herds & 31 & - & \\
\hline & Cows & 686 & 22 & $4-61$ \\
\hline \multirow[t]{2}{*}{ Data set "culling"" } & Herds & 33 & - & \\
\hline & Cows & 739 & 16 & $4-65$ \\
\hline
\end{tabular}


factor, called "corrected interval," was calculated using the formula corrected interval $=\frac{56 \text { days }}{\operatorname{interval}(\mathrm{d})}$, and was included as an additional continuous fixed effect to correct for the interval between the last DHI record before dry period and the first DHI record after calving for each cow (with a minimum interval of $56 \mathrm{~d}$ in the data set "test-day"). Starting from a full model, including the aforementioned predictors and the 2-way interactions with infection dynamics, predictors were excluded in a backward stepwise manner when statistically nonsignificant $(P>0.05)$ unless included in a significant interaction. Using data set "test-day-sub," models were run including all aforementioned predictors but also including the second test-day SCC $[2$ levels: low $(\leq 200,000$ cells $/ \mathrm{mL})$ and high $(>200,000$ cells $/ \mathrm{mL})]$.

$C M$ and Culling. The association between infection dynamics across the dry period (predictor variable of main interest) and the hazard of developing $\mathrm{CM}$ or being culled (outcome variables) was determined using survival analysis. A shared frailty survival model was fit using data set "CM" and data set "culling" with time in days between calving and the occurrence of $\mathrm{CM}$ (first case of CM versus censored) or the occurrence of culling (culled versus censored), respectively, as outcome variables. Cows that did not develop CM or were not culled before the end of the study period were censored. Herd was included as a frailty effect to correct for clustering of cows within herds. Infection dynamics across the dry period (4 levels: healthy, newly infected, cured from an existing IMI, and chronically infected), parity ( 3 levels: 2, 3, and $\geq 4$ ) and the aforementioned weighting factor "corrected interval," were included as additional categorical and continuous predictor variables (PROC PHREG, SAS 9.4, SAS Institute Inc.). The 2-way interactions with infection dynamics across the dry period were tested and maintained in the model when statistically significant $(P \leq 0.05)$. All predictors were excluded in a stepwise manner when statistically nonsignificant $(P>0.05)$ unless included in an interaction.

\section{RESULTS}

\section{Infection Dynamics Across the Dry Period}

In data set "test-day," the median parity, SCC at the last DHI record before dry-off, and interval between the last DHI record before dry period and first DHI record after calving were 2 (interquartile range of 1 to 3 ), 124,000 cells $/ \mathrm{mL}$ (interquartile range of 73,000 to 288,000 cells $/ \mathrm{mL}$ ), and $90 \mathrm{~d}$ (interquartile range of 83 to $110 \mathrm{~d}$ ), respectively. Test-day MY was normally distributed with a mean of $17.05 \mathrm{~kg} / \mathrm{d}$ (SD of 6.00).
Of 739 cows, 424 cows $(57.4 \%)$ remained healthy, 61 $(8.3 \%)$ acquired a new IMI, $170(23.0 \%)$ cured from an existing IMI, and $84(11.4 \%)$ remained chronically infected. The new IMI risk was $12.6 \%$ (61 out of 485 cows) whereas the cured IMI risk was $66.9 \%$ (170 out of 254 cows).

Of 626 cows in subset "test-day-sub," 525 (83.9\%) had a second test-day SCC in the same category (i.e., high or low) as was observed at the first test-day SCC after calving. Of the healthy cows $(\mathrm{n}=367), 91.8 \%$ ( $\mathrm{n}$ $=337$ ) had a low second test-day SCC, whereas $56.0 \%$ (28 out of 50 cows) of the cows developing a new IMI across the dry period, $80.9 \%$ (114 out of 141 cows) of the cows that cured from an IMI across the dry period, and $23.5 \%$ (16 out of 68 cows) of the chronically infected cows had a low second test-day SCC.

\section{Associations Between Infection Dynamics Across the Dry Period and Performance in the Subsequent Lactation}

Test-Day SCC. Test-day LnSCC in the subsequent lactation was higher in newly infected, cured, and chronically infected cows compared with healthy cows (data set "test day"; Table 2; Figure 1). Still, the evolution of LnSCC with DIM was significantly different between them (significant interaction between infection dynamics and DIM; Table 2 and Figure 1).

The evolution of LnSCC over time in a subsequent lactation was different when including the level of the second test-day SCC (data set "test-day-sub") than without this variable in the model, and depended on infection dynamics. Also, the effect of infection dynamics on LnSCC was modified by the level of the second test-day SCC, which was almost significant and kept in the model due to biological relevance $(P=0.055$; Table 2 and Figure 2). Healthy cows that remained low at the second test-day had a lower test-day SCC in a subsequent lactation than newly infected, cured, and chronically infected cows with a either a low or high second test-day SCC and healthy cows with a high second test-day SCC (Figure 2).

Test-Day MY. Test-day MY in the subsequent lactation was significantly associated with parity $[P<$ 0.01 ; parity 2 cows produced on average 1.94 and 1.64 $\mathrm{kg} / \mathrm{d}$ less in the subsequent lactation than parity 3 and parity $\geq 4$ cows $(P<0.01)$, respectively], DIM $(P<$ $0.01 ; \beta=-0.09), \operatorname{DIM}^{2}\left(P<0.01 ; \beta=6 \times 10^{-5}\right)$, and the corrected interval $(P=0.02 ; \beta=-3.95)$, but not with infection dynamics $(P=0.13$; Figure 3$)$.

$C M$ and Culling. In total, 79 cows suffered from CM during the study period, of which 30 (7.6\% of 397 cows), 7 (13.5\% of 52 cows), 25 ( $15.4 \%$ of 126 cows), and 17 (22.7\% of 75 cows) were healthy, newly infected, 
LIPKENS ET AL.

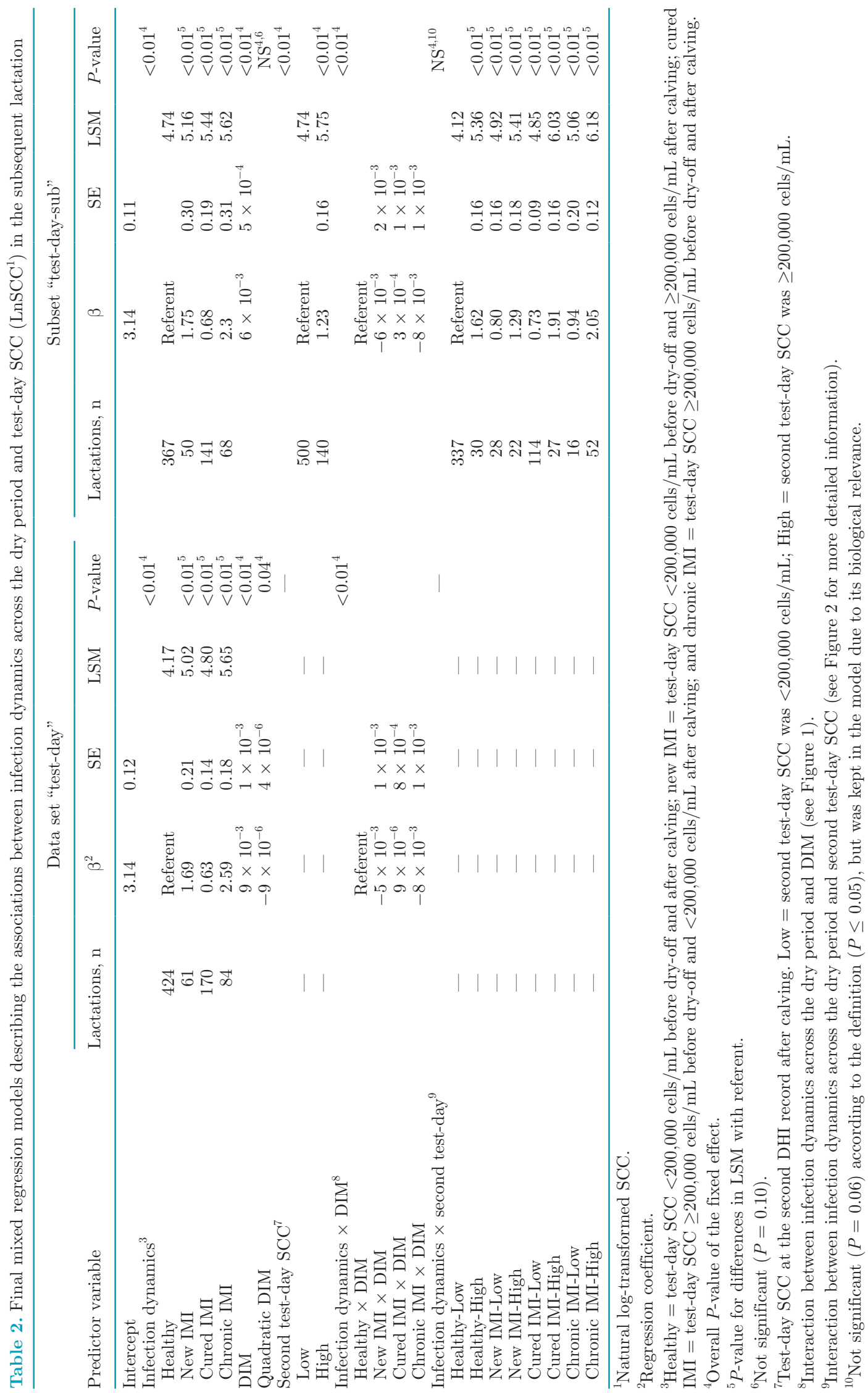




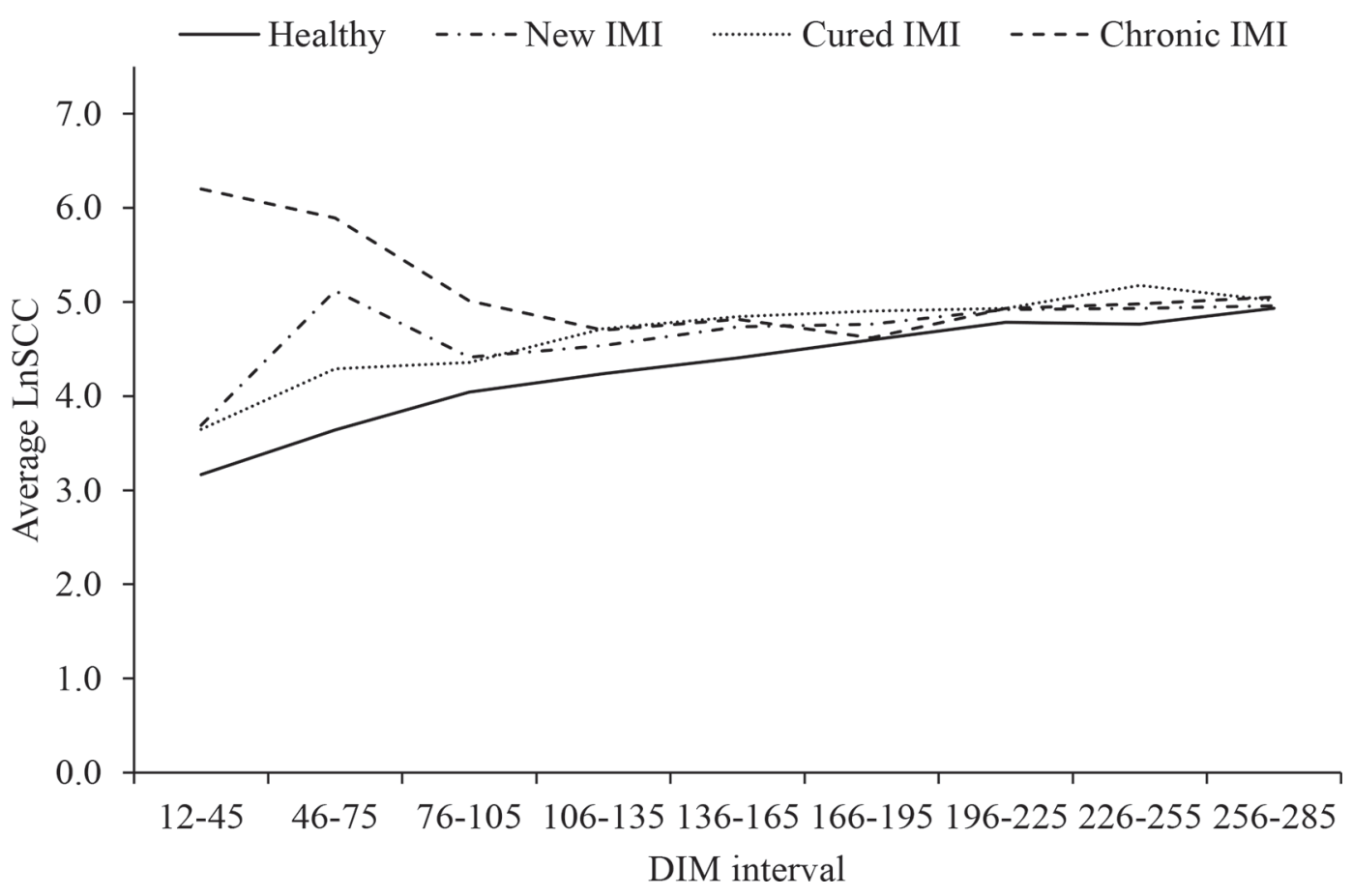

Figure 1. Association between infection dynamics across the dry period and test-day SCC $($ LnSCC; $\times 1,000$ cells $/ \mathrm{mL})$ during the subsequent lactation. Cows were considered healthy (test-day SCC $<200,000$ cells $/ \mathrm{mL}$ before and after the dry period), newly infected (new IMI; test-day SCC $<200,000$ cells $/ \mathrm{mL}$ before the dry-off and $\geq 200,000$ cells $/ \mathrm{mL}$ after calving), cured (from an existing IMI; test-day SCC $\geq 200,000$ cells/ $\mathrm{mL}$ before dry-off and $<200,000$ cells $/ \mathrm{mL}$ after calving), or chronically infected (chronic IMI; test-day SCC $\geq 200,000$ cells $/ \mathrm{mL}$ before and after the dry period).

cured from an existing IMI, and chronically infected, respectively. The median and average DIM at occurrence of the first CM case was 89 and 107 DIM, respectively. The hazard of CM was significantly higher in cows with cured and chronic IMI compared with healthy cows (hazard ratio $=2.22$ and $2.89 ; 95 \% \mathrm{CI}=1.45-3.43$ and 1.60-5.20, respectively; Table 3 and Figure 4). This was not true for cows that became newly infected across the dry period.

In total, 39 cows were culled during the study period, of which 15 (3.5\% of 424 cows), 3 (4.9\% of 61 cows), 11 (6.5\% of 170 cows), and 10 (11.9\% of 84 cows) were healthy, newly infected, cured from an existing IMI, and chronically infected, respectively. The median and average DIM at culling was 165 and 168 DIM, respectively. Chronically infected cows were more likely to be culled than healthy cows (hazard ratio $=3.68 ; 95 \%$ CI $=1.64-8.20$; Table 4 and Figure 5). Again, this was not true for cows that became infected across the dry period.

\section{DISCUSSION}

In this study, dry-period infection dynamics from a large number of cows from a large number of randomly selected commercial dairy herds using blanket dry-cow treatment were described using test-day SCC before and just after the dry period. In addition, we scrutinized associations with future performance (udder health, milk yield, and culling).

The importance of IMI at the last test-day(s) before or at drying off for the subsequent lactation performances has been studied thoroughly, especially in an increasing number of studies searching for an optimal method to implement selective dry-cow therapy (e.g., Østerås et al., 1999; Rajala-Schultz et al., 2011; Scherpenzeel et al., 2014). Combining the SCC information before and after drying off has previously been demonstrated to be useful by Pantoja et al. (2009a), yet only the effect on the first test-day MY post-calving, and not the effect on test-day SCC and MY in the remainder of the subsequent lactation, was studied. The current study revealed that entering the dry period with an IMI negatively affected udder health (test-day SCC and CM risk) as well as culling hazard in the subsequent lactation, reinforcing the need for excellent udder health management during lactation and before the dry period. This shows the value of analyzing DHI data to pinpoint specific udder health issues on dairy farms; when combined with regular culturing of milk to identify the mastitis-causing pathogens in the herd, udder health can be managed appropriately. 
In Flanders in 2012, $46.7 \%$ of all dairy herds participated in milk recording, housing 50 lactating cows on average (CRV). However, the 33 enrolled herds in this study were larger, averaging 68 lactating cows. It is somewhat disappointing that only $23.6 \%$ of cows fulfilled all requirements for inclusion in the study. When commercial dairy farms are included, the quality of DHI recording differs between herds. Most herds struggled to provide DHI recordings on a regular basis, and 6 herds skipped one or more DHI recordings during the study period. Unfortunately, at the cow level, missing SCC values also occurred regularly. On average, we needed $98 \mathrm{~d}$ to collect all data to define dry-cow infection dynamics and its effect for 1 cow during a 1-yr study period, which explains why only about onefourth of the cows were enrolled in data set "test-day," and some herds contributed more cows to the data set than others (representing between 0.5 and $8.8 \%$ of the 739 cows in data set "test-day").

Many studies have reported associations between IMI during the dry period and IMI during lactation at the quarter-level (e.g., Oliver and Mitchell, 1983; Todhunter et al., 1991; Bradley and Green, 2000), yet only a few studies have described infection dynamics across the dry period (i.e., healthy, new IMI, cured IMI, and chronic IMI) and consequently its effect on cow performance in the subsequent lactations. Although SCC is only a proxy for IMI, analyzing test-day SCC before and after the dry period is the most feasible way to monitor infection dynamics across the dry period (Dufour and Dohoo, 2012). Using a threshold of 200,000 cells $/ \mathrm{mL}, 12.6 \%$ of cows acquired a new IMI in the dry period, whereas $66.9 \%$ of the cows cured from an existing IMI, despite the use of long-acting antimicrobials. This implies that dry-cow therapy alone cannot guarantee good udder health across the dry period. Thus, additional measures such as decreasing infection pressure during the dry period, preventing bacteria from entering the udder by use of internal teat sealers (Huxley et al., 2002), improving cows' immune status (Sordillo and Streicher, 2002), and culling cows that have limited odds of curing (Østerås et al., 1999) are necessary to control mastitis during the dry period. The new IMI risk was lower than that reported in Canadian, American, and British research, which varied between 19 and 22.4\% (Cook et al., 2002; Pantoja et al., 2009a; Fauteux et al., 2014; Henderson et al., 2016) and the $15.7 \%$ obtained by Pantoja et al. (2009a) via bacteriological culturing. Meanwhile, the cured IMI risk in our study corresponded well to the reported cured IMI risks of 63 to $71.4 \%$ using test-day SCC (Pantoja et al., 2009a; Madouasse et al., 2010;
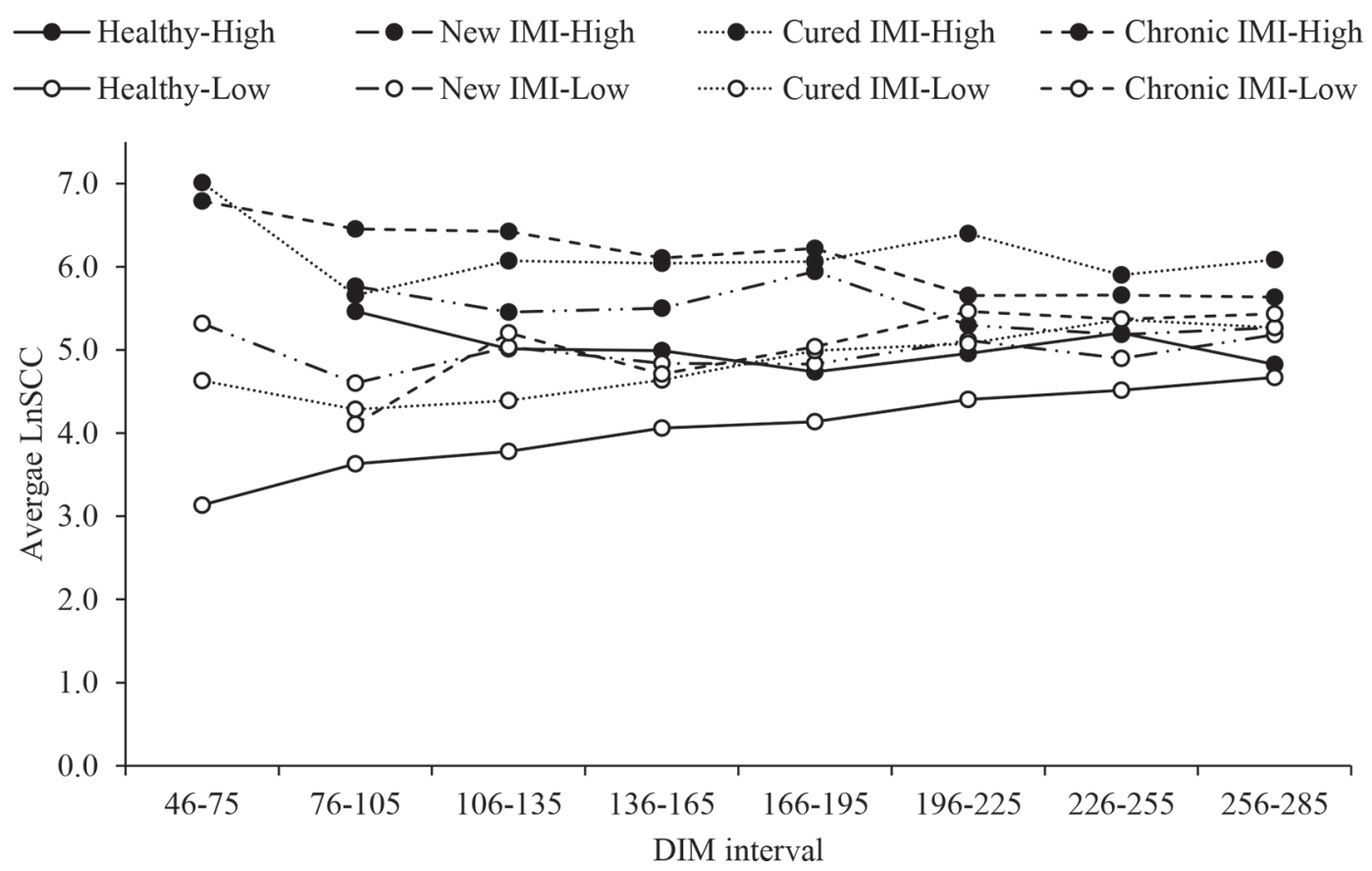

Figure 2. Association between infection dynamics across the dry period and test-day SCC $(\mathrm{LnSCC}, \times 1,000 \mathrm{cells} / \mathrm{mL})$ during the subsequent lactation, corrected for the second test-day SCC (low: $<200,000$ cells $/ \mathrm{mL}$ and high: SCC $\geq 200,000$ cells $/ \mathrm{mL}$ ). Cows were considered healthy (test-day SCC $<200,000$ cells $/ \mathrm{mL}$ before and after the dry period), newly infected (new IMI; test-day SCC $<200,000$ cells $/ \mathrm{mL}$ before the dry-off and $\geq 200,000$ cells $/ \mathrm{mL}$ after calving), cured (from an existing IMI; test-day SCC $\geq 200,000$ cells/mL before dry-off and $<200,000$ cells/mL after calving), or chronically infected (chronic IMI; test-day SCC $\geq 200,000$ cells $/ \mathrm{mL}$ before and after the dry period). 
Table 3. Final shared frailty survival models describing the association between infection dynamics across the dry period and the hazard of developing clinical mastitis in the subsequent lactation

\begin{tabular}{lrccccc}
\hline Predictor variable & $\mathrm{n}$ & $\beta^{1}$ & $\mathrm{SE}$ & $\mathrm{HR}^{2}$ & $95 \% \mathrm{CI} \mathrm{HR}^{2}$ & $P$-value \\
\hline Infection dynamics $^{3}$ & 397 & Referent & & & & $<0.01^{4}$ \\
Healthy & 52 & 0.67 & 0.44 & 1.96 & $0.86-4.45$ & \\
New IMI & 162 & 0.80 & 0.28 & 2.22 & $1.45-3.43$ & \\
Cured IMI & 75 & 1.06 & 0.33 & 2.89 & $1.60-5.20$ & \\
Chronic IMI & &
\end{tabular}

${ }^{1}$ Regression coefficient.

${ }^{2}$ Hazard ratio and $95 \%$ CI of HR.

${ }^{3}$ Healthy = test-day SCC $<200,000$ cells $/ \mathrm{mL}$ before dry-off and after calving; new IMI = test-day SCC $<200,000$ cells $/ \mathrm{mL}$ before dry-off and $\geq 200,000$ cells/mL after calving; cured IMI $=$ test-day $\mathrm{SCC} \geq 200,000$ cells/mL before dry-off and $<200,000$ cells/mL after calving; and chronic IMI $=$ test-day $\mathrm{SCC} \geq 200,000$ cells/ $\mathrm{mL}$ before dry-off and after calving.

${ }^{4}$ Overall $P$-value of the fixed effect.

Fauteux et al., 2014; Henderson et al., 2016) and with cured IMI risks obtained via bacteriological culturing of $69.0 \%$ (Pantoja et al., 2009a). Still, as the early lactation is notorious for udder infections (Bradley and Green, 2004), the new IMI proportion might be lower and the cured IMI proportion might be higher than portrayed by infection dynamics in this study. Thus, the true protection against new infections and the cure of existing infections due to dry-cow therapy during the dry period is probably biased.

Interestingly, in our study, in addition to the cows with chronic IMI, as was also reported for quarters by
Green et al. (2002) and Pantoja et al. (2009b), cows that cured from an IMI during the dry period were more likely to develop CM in the subsequent lactation and had a higher SCC (but not a lower MY) compared with healthy herdmates. A possible explanation for this finding is that cows that cure from an IMI simply remain more susceptible to new IMI, due to anatomical damage to the teat canal barrier (Rainard and Riollet, 2006). A second hypothesis is that cows did not cure bacteriologically across the dry period despite their test-day milk SCC being below 200,000 cells/mL at the first DHI recording after calving. Other well-known

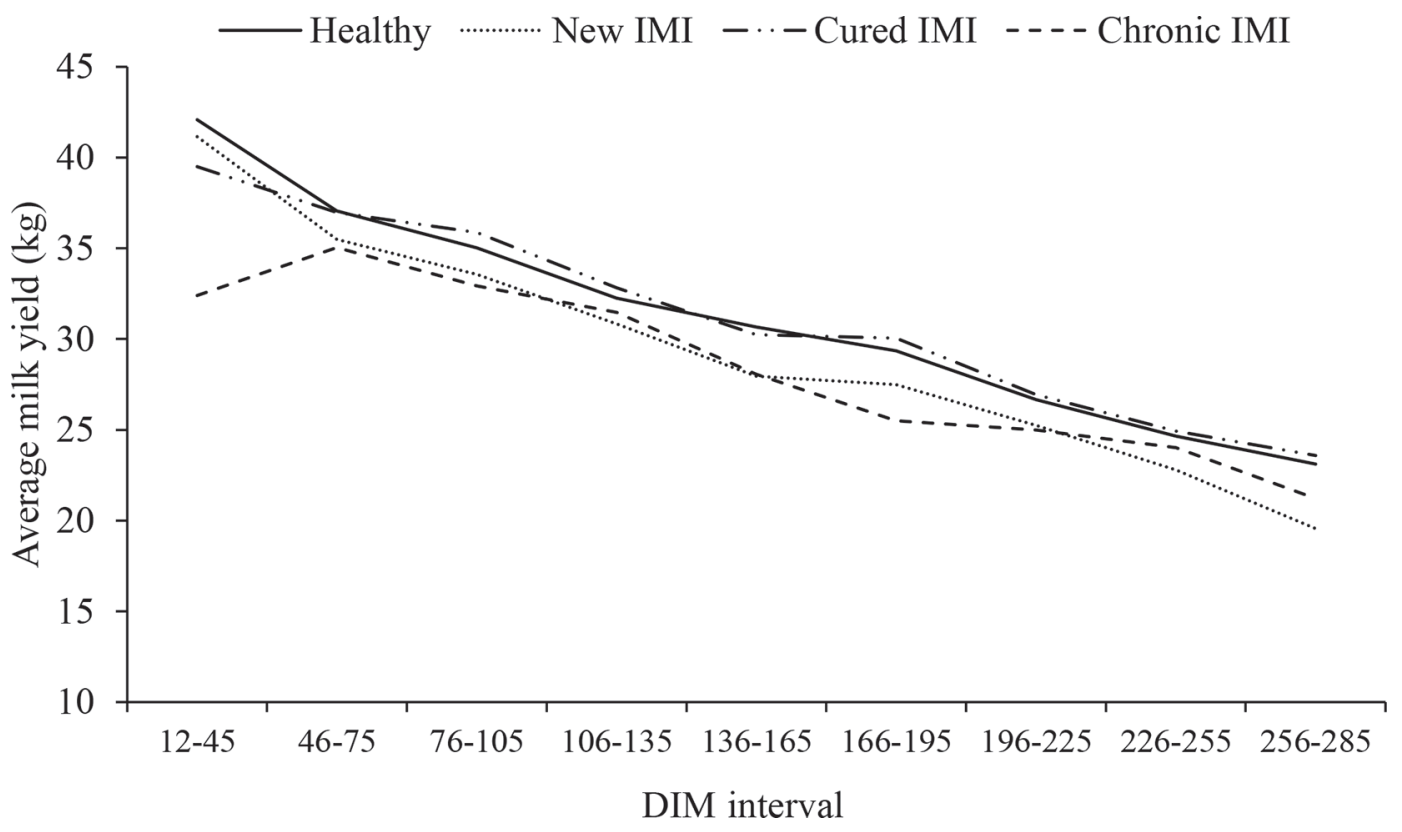

Figure 3. Association between infection dynamics across the dry period and test-day milk yield during the subsequent lactation for all parities combined and per parity. Cows were considered healthy (test-day SCC $<200,000$ cells/mL before and after the dry period), newly infected (new IMI; test-day SCC $<200,000$ cells/mL before the dry-off and $\geq 200,000$ cells/mL after calving), cured (from an existing IMI; test-day SCC $\geq 200,000$ cells $/ \mathrm{mL}$ before dry-off and $<200,000$ cells/mL after calving), or chronically infected (chronic IMI; test-day SCC $\geq 200,000$ cells $/ \mathrm{mL}$ before and after the dry period). 
Table 4. Final shared frailty survival models describing the association between infection dynamics across the dry period and the culling hazard in the subsequent lactation

\begin{tabular}{lrccccc}
\hline Predictor variable & $\mathrm{n}$ & $\beta^{1}$ & $\mathrm{SE}$ & $\mathrm{HR}^{2}$ & $95 \% \mathrm{CI} \mathrm{HR}^{2}$ & $P$-value \\
\hline Infection dynamics $^{3}$ & 424 & Referent & & & & $0.01^{4}$ \\
Healthy & 61 & 0.30 & 0.63 & 1.35 & $0.39-4.64$ & \\
New IMI & 170 & 0.69 & 0.40 & 2.00 & $0.91-4.37$ & \\
Cured IMI & 84 & 1.30 & 0.41 & 3.68 & $1.64-8.20$ & \\
Chronic IMI & &
\end{tabular}

${ }^{1}$ Regression coefficient.

${ }^{2}$ Hazard ratio and $95 \% \mathrm{CI}$ of $\mathrm{HR}$.

${ }^{3}$ Healthy $=$ test-day SCC $<200,000$ cells $/ \mathrm{mL}$ before dry-off and after calving; New $=$ test-day $\mathrm{SCC}<200,000$ cells/mL before dry-off and $\geq 200,000$ cells/mL after calving; Cured $=$ test-day $\mathrm{SCC} \geq 200,000$ cells/mL before dry-off and $<200,000$ cells $/ \mathrm{mL}$ after calving; and Chronic $=$ test-day $\mathrm{SCC} \geq 200,000$ cells/mL before dry-off and after calving.

${ }^{4}$ Overall $P$-value of the fixed effect.

cow-level factors that affect the risk of IMI in the subsequent lactation include teat apex hyperkeratosis and diameter (Breen et al., 2009; Guarín and Ruegg, 2016; Pantoja et al., 2016), udder and leg hygiene (Schreiner and Ruegg, 2003), negative energy balance (Suriyasathaporn et al., 2000), MY at drying off (Huxley et al., 2002; Dingwell et al., 2004), and genetic predisposition (Detilleux, 2009), yet these were not monitored in our study.

A significant proportion of culling (Fetrow et al., 2006) and CM (Bradley and Green, 2004) occurs during early lactation; although these events were only monitored after the first DHI record (taking place between
12 and 42 DIM) in the present study, the infection dynamics were still significantly associated with culling and CM. As expected (but not previously studied), cows with chronic IMI were more likely to be culled in the subsequent lactation up to 285 DIM compared with healthy cows. This suggests compliance with general recommendations to cull chronically infected cows as these cows generally perform badly in the subsequent lactation (Green et al., 2002; Pantoja et al., 2009b). The fact that culled cows produced approximately 1.4 $\mathrm{kg} / \mathrm{d}$ less at the last test-day before dry-off than cows that were not culled (data not shown) suggests that suboptimal MY might have played at least a partial

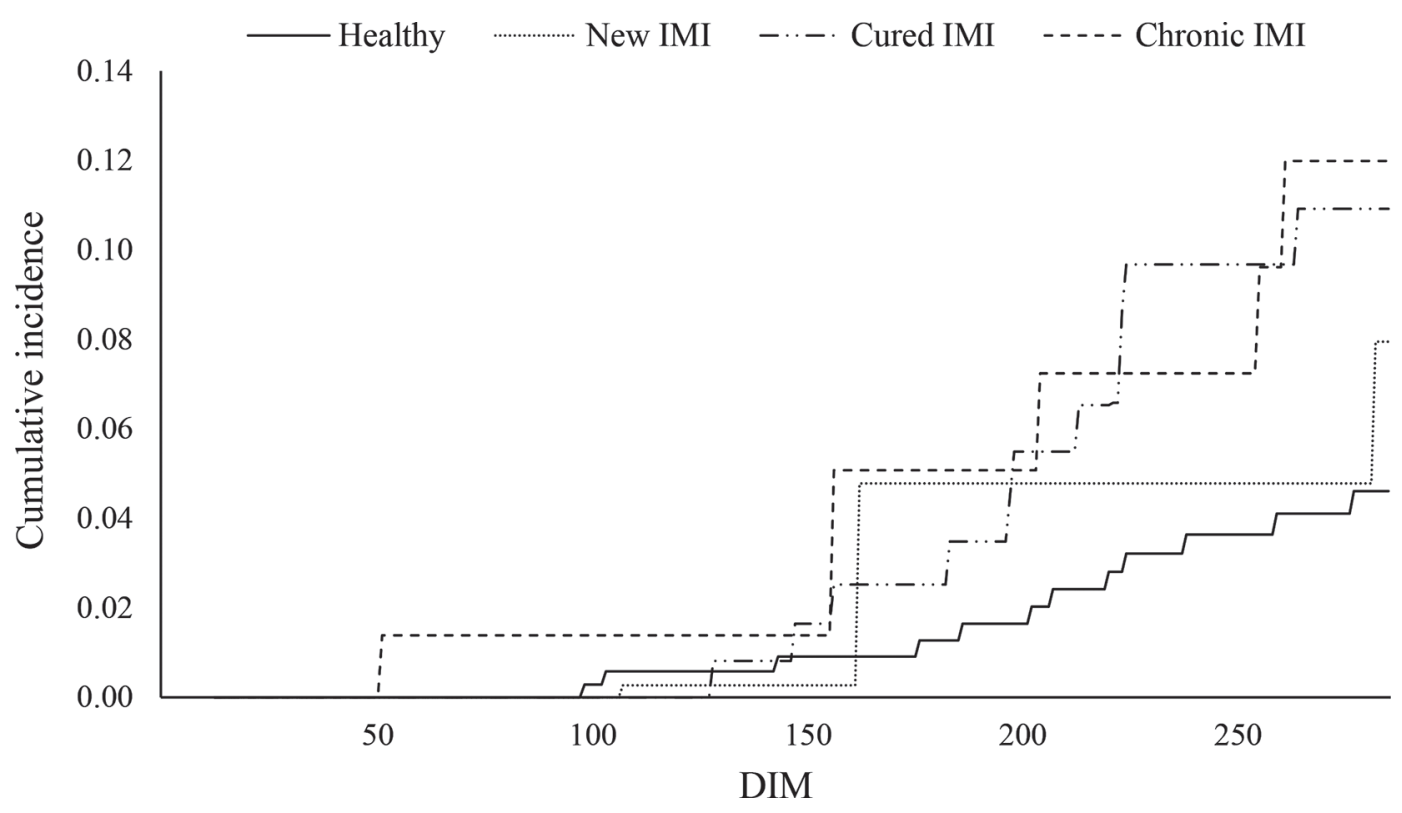

Figure 4. Kaplan-Meier graph showing the association between infection dynamics across the dry period and the hazard of developing clinical mastitis in the subsequent lactation, from 12 (after the first post-calving DHI record) to 285 DIM. Cows were considered healthy (test-day SCC $<200,000$ cells $/ \mathrm{mL}$ before and after the dry period), newly infected (new IMI; test-day SCC $<200,000$ cells $/ \mathrm{mL}$ before the dry-off and $\geq 200,000$ cells/mL after calving), cured (from an existing IMI; test-day SCC $\geq 200,000$ cells/mL before dry-off and $<200,000$ cells/mL after calving), or chronically infected (chronic IMI; test-day SCC $\geq 200,000$ cells/mL before and after the dry period). 
role in the culling decision. Although not significantly associated, cows that entered the dry period with an IMI yet cured from it tended to be more likely to be culled than healthy cows, possibly because of a significantly higher CM hazard. In any case, taking an IMI from lactation into the dry period was far from optimal.

The second test-day SCC was measured starting from 34 DIM, thus late in or somewhat after the transition period, and provided additional information to the first test-day SCC value. Healthy cows with a low second test-day SCC still had a lower test-day SCC in the subsequent lactation compared with newly infected cows, cows with a chronic IMI, and even cows that cured from an IMI with either a low or high second test-day SCC, which implies that management should aim for a proportion of healthy cows with a low second test-day SCC in the herd higher than the $53.8 \%$ found in the current study. Cured IMI cows (compared with healthy cows) were about twice as likely to shift again to a high second test-day SCC, indicating that these cows were either not bacteriologically cured in the dry period or that they contracted a new IMI after calving. This resulted in significantly higher test-day SCC in the subsequent lactation compared with healthy cows. These findings might also explain why cows that cured from an existing IMI during the dry period were more likely to contract CM during the next lactation. Strikingly, more than $50 \%$ of the newly infected cows could be considered healthy based on their second test-day SCC. Possibly, the acquired IMI present after calving cured with the help of the restored innate and acquired immunity, which might explain why new IMI cows were not at higher risk for $\mathrm{CM}$ and culling compared with healthy cows. Also, non-aureus staphylococci infections are highly prevalent at calving (Pantoja et al., 2009a; Piepers et al., 2011) and are known as a group to moderately increase the SCC (Piepers et al., 2013; Supré et al., 2011), although some authors have described a high spontaneous cure of these infections in early lactation (e.g., Oliver and Jayarao, 1997; Taponen et al., 2006), resulting in an early-lactation SCC decrease. Another explanation is that the SCC at the first DHI record is physiological higher than SCC later in the same lactation (e.g., Dohoo, 1993; Madouasse et al., 2012), in spite of the 12 DIM threshold used to enroll the first DHI record after calving.

Unlike the findings reported by Pantoja et al. (2009a), infection dynamics across the dry period and MY in the subsequent lactation were not associated. When including LnSCC at test-day as a predictor variable in the model for MY, a significant negative association was found, as expected (data not shown), and it resulted in a remarkable reduction of the $P$-value of the infection dynamics. Therefore, we can hypothesize that the high SCC because of an IMI during the dry period is the main cause of a decreased MY in the subsequent lactation, rather than impairment of mammary function, as was concluded for heifers (De Vliegher et al., 2005). Of course, as SCC is only an estimation of the infection status of cows, the accuracy of predicting the outcome of infection dynamics can probably be increased when additional information is taken into account, such as

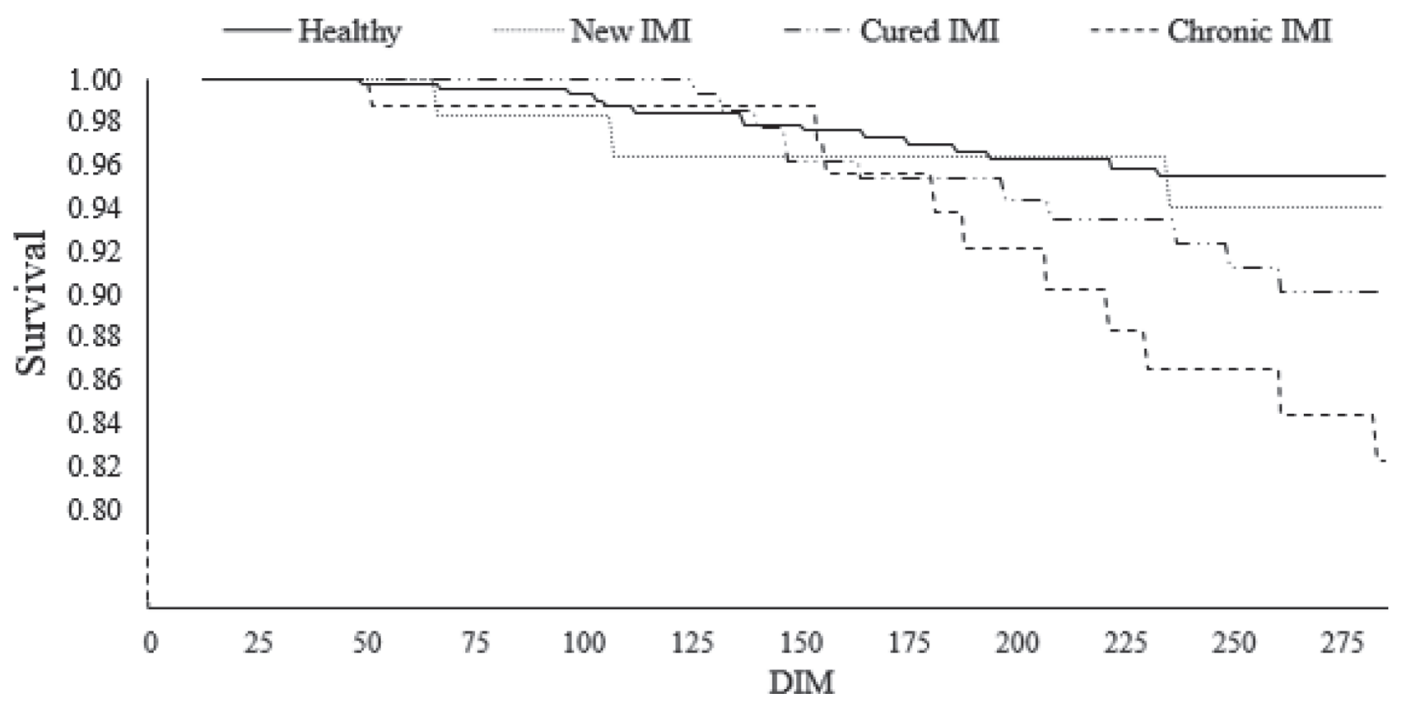

Figure 5. Kaplan-Meier graph showing the association between infection dynamics across the dry period and the culling hazard in the subsequent lactation, from 12 (after the first post-calving DHI record) to 285 DIM. Cows were considered healthy (test-day SCC $<200,000$ cells/ $\mathrm{mL}$ before and after the dry period), newly infected (new IMI; test-day SCC $<200,000$ cells $/ \mathrm{mL}$ before the dry-off and $\geq 200,000$ cells $/ \mathrm{mL}$ after calving), cured (from an existing IMI; test-day SCC $\geq 200,000$ cells/mL before dry-off and $<200,000$ cells/mL after calving), or chronically infected (chronic IMI; test-day $\mathrm{SCC} \geq 200,000$ cells $/ \mathrm{mL}$ before and after the dry period). 
MY and DIM at the last milk recording or the 3 last test-day SCC before the dry period, rather than only the last (Torres et al., 2008; Vasquez et al., 2018).

\section{CONCLUSIONS}

Healthy cows across the dry period outperformed newly infected, cured, and chronically infected cows when looking at SCC, CM, and culling hazard in the subsequent lactation. Moreover, healthy cows that remained healthy in early lactation had the lowest SCC in the entire subsequent lactation compared with cows that had an infection either at dry-off, at calving, or in early lactation. Cows with an IMI at dry-off, regardless of whether they managed to cure from the infection, were at a higher risk of CM and elevated SCC in the subsequent lactation compared with healthy cows. Additionally, cows with a chronic IMI across the dry period performed the worst in terms of CM risk and SCC in the subsequent lactation, but were also more likely to be culled compared with healthy cows. Therefore, it is recommended to focus on preventing IMI during lactation; for example, by implementing the National Mastitis Council 10-point program, rather than on curing an existing IMI at dry-off or even preventing new IMI during the dry period. Test-day MY was not associated with infection dynamics across the dry period but depended on SCC at test day in the subsequent lactation. Besides monitoring infection dynamics during lactation, regular evaluation of infection dynamics across the dry period based on a specific SCC threshold (we used 200,000 cells/mL) should be implemented as part of any herd health monitoring program to monitor and further improve the udder health before, during, and after the dry period.

\section{ACKNOWLEDGMENTS}

This research was funded by a PhD grant (no. 141088) of the Agency for Innovation through Science and Technology in Flanders (IWT Vlaanderen).

\section{REFERENCES}

Aidara-Kane, A., F. J. Angulo, J. M. Conly, Y. Minato, E. K. Silbergeld, S. A. McEwen, and P. Collignon. 2018. World Health Organization (WHO) guidelines on use of medically important antimicrobials in food-producing animals. Antimicrob. Resist. Infect. Control. 7:7. https://doi.org/10.1186/s13756-017-0294-9.

Bai, Z., M. R. F. Lee, L. Ma, S. Ledgard, O. Oenema, G. L. Velthof, W. Ma, M. Guo, Z. Zhao, S. Wei, S. Li, X. Liu, P. Havlík, J. Luo, C. Hu, and F. Zhang. 2018. Global environmental costs of China's thirst for milk. Glob. Chang. Biol. 24:2198-2211.

Bradley, A. J., and M. J. Green. 2000. A study of the incidence and significance of intramammary enterobacterial infections acquired during the dry period. J. Dairy Sci. 83:1957-1965.
Bradley, A. J., and M. J. Green. 2001. An investigation of the impact of intramammary antibiotic dry cow therapy on clinical coliform mastitis. J. Dairy Sci. 84:1632-1639.

Bradley, A. J., and M. J. Green. 2004. The importance of the nonlactating period in the epidemiology of intramammary infection and strategies for prevention. Vet. Clin. North Am. Food Anim. Pract. 20:547-568.

Breen, J. E., M. J. Green, and A. J. Bradley. 2009. Quarter and cow risk factors associated with the occurrence of clinical mastitis in dairy cows in the United Kingdom. J. Dairy Sci. 92:2551-2561.

Cook, N. B., T. B. Bennett, K. M. Emery, and K. V. Nordlund. 2002. Monitoring nonlactating cow intramammary infection dynamics using DHI somatic cell count data. J. Dairy Sci. 85:1119-1126.

De Vliegher, S., H. W. Barkema, H. Stryhn, G. Opsomer, and A. de Kruif. 2005. Impact of early lactation somatic cell count in heifers on milk yield over the first lactation. J. Dairy Sci. 88:938-947.

Detilleux, J. C. 2009. Genetic factors affecting susceptibility to udder pathogens. Vet. Microbiol. 134:157-164.

Dingwell, R. T., K. E. Leslie, Y. H. Schukken, J. M. Sargeant, L. L. Timms, T. F. Duffield, G. P. Keefe, D. F. Kelton, K. D. Lissemore, and J. Conklin. 2004. Association of cow and quarter-level factors at drying-off with new intramammary infections during the dry period. Prev. Vet. Med. 63:75-89.

Dohoo, I. R. 1993. An evaluation of the validity of individual cow SCC from cows in early lactation. Prev. Vet. Med. 16:103-110.

Dohoo, I. R., A. H. Meek, S. W. Martin, and D. A. Barnum. 1981. Use of total and differential somatic cell counts from composite milk samples to detect mastitis in individual cows. Can. J. Comp. Med. 45:8-14.

Dufour, S., and I. R. Dohoo. 2012. Monitoring dry period intramammary infection incidence and elimination rates using somatic cell count measurements. J. Dairy Sci. 95:7173-7185.

Dufour, S., A. Frechette, H. W. Barkema, A. Mussell, and D. T. Soholl. 2011. Invited review: Effect of udder health management practices on herd somatic cell count. J. Dairy Sci. 94:563-579.

Fauteux, V., J. P. Roy, D. T. Scholl, and E. Bouchard. 2014. Benchmarks for evaluation and comparison of udder health status using monthly individual somatic cell count. Can. Vet. J. 55:741-748.

Fetrow, J., K. V. Nordlund, and H. D. Norman. 2006. Invited review: Culling: Nomenclature, definitions, and recommendations. J. Dairy Sci. 89:1896-1905.

Green, M. J., L. E. Green, G. F. Medley, Y. H. Schukken, and A. J. Bradley. 2002. Influence of dry period bacterial intramammary infection on clinical mastitis in dairy cows. J. Dairy Sci. 85:25892599.

Guarín, J. F., and P. L. Ruegg. 2016. Short communication: Pre- and postmilking anatomical characteristics of teats and their associations with risk of clinical mastitis in dairy cows. J. Dairy Sci. 99:8323-8329

Henderson, A. C., C. D. Hudson, A. J. Bradley, V. E. Sherwin, and M. J. Green. 2016. Prediction of intramammary infection status across the dry period from lifetime cow records. J. Dairy Sci. 99:5586-5595.

Huxley, J. N., M. J. Green, L. E. Green, and A. J. Bradley. 2002. Evaluation of the efficacy of an internal teat sealer during the dry period. J. Dairy Sci. 85:551-561.

Madouasse, A., W. J. Browne, J. N. Huxley, F. Toni, A. J. Bradley, and M. J. Green. 2012. Risk factors for a high somatic cell count at the first milk recording in a large sample of UK dairy herds. J. Dairy Sci. 95:1873-1884.

Madouasse, A., J. N. Huxley, W. J. Browne, A. J. Bradley, and M. J. Green. 2010. Somatic cell count dynamics in a large sample of dairy herds in England and Wales. Prev. Vet. Med. 96:56-64.

Oliver, S. P., and B. M. Jayarao. 1997. Coagulase-negative staphylococcal intramammary infections in cows and heifers during the nonlactating and periparturient periods. Zentralbl. Veterinarmed. 44:355-363.

Oliver, S. P., and B. A. Mitchell. 1983. Susceptibility of bovine mammary gland to infections during the dry period. J. Dairy Sci. $66: 1162-1166$ 
Østerås, O., V. L. Edge, and S. W. Martin. 1999. Determinants of success or failure in the elimination of major mastitis pathogens in selective dry cow therapy. J. Dairy Sci. 82:1221-1231.

Pantoja, J. C. F., A. P. Almeida, B. dos Santos, and R. S. Rossi. 2016. An investigation of risk factors for two successive cases of clinical mastitis in the same lactation. Livest. Sci. 194:10-16.

Pantoja, J. C. F., C. Hulland, and P. L. Ruegg. 2009a. Dynamics of somatic cell counts and intramammary infections across the dry period. Prev. Vet. Med. 90:43-54.

Pantoja, J. C. F., C. Hulland, and P. L. Ruegg. 2009b. Somatic cell count status across the dry period as a risk factor for the development of clinical mastitis in the subsequent lactation. J. Dairy Sci. 92:139-148.

Piepers, S., K. Peeters, G. Opsomer, H. W. Barkema, K. Frankena, and S. De Vliegher. 2011. Pathogen group specific risk factors at herd, heifer and quarter levels for intramammary infections in early lactating dairy heifers. Prev. Vet. Med. 99:91-101.

Piepers, S., Y. H. Schukken, P. Passchyn, and S. De Vliegher. 2013. The effect of intramammary infection with coagulase-negative staphylococci in early lactating heifers on milk yield throughout first lactation revisited. J. Dairy Sci. 96:5095-5105.

Rainard, P., and C. Riollet. 2006. Innate immunity of the bovine mammary gland. Vet. Res. 37:369-400.

Rajala-Schultz, P. J., A. H. Torres, and F. J. Degraves. 2011. Milk yield and somatic cell count during the following lactation after selective treatment of cows at dry-off. J. Dairy Res. 78:489-499.

Scherpenzeel, C. G., I. E. den Uijl, G. van Schaik, R. G. Olde Riekerink, J. M. Keurentjes, and T. J. Lam. 2014. Evaluation of the use of dry cow antibiotics in low somatic cell count cows. J. Dairy Sci. 97:3606-3614

Schreiner, D. A., and P. L. Ruegg. 2003. Relationship between udder and leg hygiene scores and subclinical mastitis. J. Dairy Sci. 86:3460-3465.

Sordillo, L. M., and K. L. Streicher. 2002. Mammary gland immunity and mastitis susceptibility. J. Mammary Gland Biol. Neoplasia $7: 135-146$.
Supré, K., F. Haesebrouck, R. N. Zadoks, M. Vaneechoutte, S. Piepers, and S. De Vliegher. 2011. Some coagulase-negative staphylococcus species affect udder health more than others. J. Dairy Sci. 94:2329-2340.

Suriyasathaporn, W., C. Heuer, E. N. Noordhuizen-Stassen, and Y. H. Schukken. 2000. Hyperketonemia and the impairment of udder defense: A review. Vet. Res. 31:397-412.

Taponen, S., H. Simojoki, M. Haveri, H. D. Larsen, and S. Pyorala. 2006. Clinical characteristics and persistence of bovine mastitis caused by different species of coagulase-negative staphylococci identified with API or AFLP. Vet. Microbiol. 115:199-207.

Todhunter, D. A., K. L. Smith, J. S. Hogan, and P. S. Schoenberger. 1991. Gram-negative bacterial infections of the mammary gland in cows. Am. J. Vet. Res. 52:184-188.

Torres, A. H., P. J. Rajala-Schultz, F. J. Degraves, and K. H. Hoblet. 2008. Using dairy herd improvement records and clinical mastitis history to identify subclinical mastitis infections at dry-off. J. Dairy Res. 75:240-247.

Vasquez, A. K., D. V. Nydam, C. Foditsch, M. Wieland, R. Lynch, S. Eicker, and P. D. Virkler. 2018. Use of a culture-independent on-farm algorithm to guide the use of selective dry-cow antibiotic therapy. J. Dairy Sci. 101:5345-5361.

Verbeke, J., S. Piepers, K. Supré, and S. De Vliegher. 2014. Pathogenspecific incidence rate of clinical mastitis in Flemish dairy herds, severity, and association with herd hygiene. J. Dairy Sci. 97:69266934.

Wankhade, P. R., A. Manimaran, A. Kumaresan, S. Jeyakumar, K. P. Ramesha, V. Sejian, D. Rajendran, and M. R. Varghese. 2017. Metabolic and immunological changes in transition dairy cows: A review. Vet. World 10:1367-1377.

Whist, A. C., and O. Østeras. 2007. Associations between somatic cell counts at calving or prior to dry-off and clinical mastitis in the remaining or subsequent lactation. J. Dairy Res. 74:66-73. 